\title{
Modulation of iron homeostasis in macrophages by bacterial intracellular pathogens
}

Xin Pan ${ }^{1}$, Batcha Tamilselvam¹, Eric J Hansen ${ }^{1,2}$, Simon Daefler ${ }^{1 *}$

\begin{abstract}
Background: Intracellular bacterial pathogens depend on acquisition of iron for their success as pathogens. The host cell requires iron as an essential component for cellular functions that include innate immune defense mechanisms. The transferrin receptor TfR1 plays an important part for delivering iron to the host cell during infection. Its expression can be modulated by infection, but its essentiality for bacterial intracellular survival has not been directly investigated.

Results: We identified two distinct iron-handling scenarios for two different bacterial pathogens. Francisella tularensis drives an active iron acquisition program via the TfR1 pathway program with induction of ferrireductase (Steap3), iron membrane transporter Dmt1, and iron regulatory proteins IRP1 and IRP2, which is associated with a sustained increase of the labile iron pool inside the macrophage. Expression of TfR1 is critical for Francisella's intracellular proliferation. This contrasts with infection of macrophages by wild-type Salmonella typhimurium, which does not require expression of TfR1 for successful intracellular survival. Macrophages infected with Salmonella lack significant induction of Dmt1, Steap3, and IRP1, and maintain their labile iron pool at normal levels.

Conclusion: The distinction between two different phenotypes of iron utilization by intracellular pathogens will allow further characterization and understanding of host-cell iron metabolism and its modulation by intracellular bacteria.
\end{abstract}

\section{Background}

Iron is required by a wide variety of intracellular bacterial pathogens to achieve full virulence. Deprivation of iron in-vivo and in-vitro severely reduces the pathogenicity of Mycobacterium tuberculosis, Coxiella burnettii, Legionella pneumophila, and Salmonella typhimurium [1-4]. Attempts to withhold iron by sequestering free iron during infection is a major defense strategy used by many species [5]. Inflammatory signaling cascades during infection lead to a reduction in available free iron and sequestration of iron in the reticuloendothelial system (RES) [6]. On the other hand, iron is needed by host cells for cellular functions and first line defense mechanisms [7]. Iron homeostasis also affects macrophage and lymphocyte effector pathways of the innate and adaptive immune response $[6,8]$.

Iron homeostasis in the macrophage is determined by uptake processes through lactoferrin, transferrin, divalent

\footnotetext{
* Correspondence: simon.daefler@mssm.edu
${ }^{1}$ Mount Sinai School of Medicine, One Gustave Levy Place, New York, NY

* Correspondence: simon.daefler@mssm.edu
${ }^{1}$ Mount Sinai School of Medicine, One Gustave Levy Place, New York, NY 10570, USA
} 10570, USA

\section{) Biomed Central}

(c) 2010 Pan et al; licensee BioMed Central Ltd. This is an Open Access article distributed under the terms of the Creative Commons Attribution License (http://creativecommons.org/licenses/by/2.0), which permits unrestricted use, distribution, and reproduction in any medium, provided the original work is properly cited. metal transporter (DMT-1), phagocytosis of senescent erythrocytes, and by export through ferroportin (Fpn1) [8]. Transferrin and its receptor (TfR1) play an important role during infection of macrophages with bacterial pathogens that prefer an intracellular lifestyle. Expression of TfR1 can in turn be modulated by bacterial infections [9]. Intracellular bacteria such as Mycobacterium tuberculosis and Ehrlichia $[10,11]$ actively recruit TfR 1 to the bacteriumcontaining vacuole. However, the requirement of TfR1 for bacterial pathogenesis has not been directly addressed.

We sought here to determine if iron delivery through the transferrin receptor (TfR1) is essential for the success of two intracellular pathogens with differing intracellular life-styles, Salmonella typhimurium and Francisella tularensis. Salmonella typhimurium represents a well-characterized model intracellular pathogen, which causes typhoid fever in the mouse. Salmonella uncouples from the phagolysosomal pathway in macrophages and remains in a protected intracellular niche inside a vacuole [12]. The Salmonella-containing vacuole $(\mathrm{SCV})$ interacts with multiple endocytic 
pathways and avoids its fusion with acidic lysosomes. This is similar to infection with Chlamydia, Legionella, and Mycobacteriae. In contrast, Francisella tularensis, causative agent of tularemia and considered a category A biothreat because of its high infectivity and high casefatality rate when untreated, enters the macrophage in a vesicle, but escapes from its enclosure into the cytosol after lysis of its vesicle within sixty minutes after entry into the host cell [13]. Both Francisella and Salmonella require iron for successful intracellular proliferation [14]. A Francisella operon, figABCD, has recently been described as being involved in iron acquisition [15,14]. Recent studies from two groups using random transposon mutagenesis of either F. tularensis LVS [16] or F. novicida [17] showed that insertions into the figA, figB, $f i g C$, or $f e o B$ genes caused reduced virulence of these mutants. While transposon insertions may cause polar effects on downstream genes, these data strongly suggest that expression of these particular gene products is essential for full virulence of Francisella species. In addition, expression of certain F.tularenis virulence genes is clearly regulated by iron availability $[14,18]$.

After exposure to just a few aerosolized Francisella, serum iron decreases very rapidly [19]. Bacteria counteract the host's withholding of iron by secretion of iron chelators, which are termed siderophores, or by directly interacting with host iron-binding proteins [20-22]. The Francisella figABCDEF gene cluster (also referred to as $f_{s} l A B C D E F$ [23]) encodes such a siderophore, which belongs to the polycarboxylate family such as produced by Rhizopus species $[15,14]$.

All these studies suggest that a delicate balance of the iron available for bacteria and for host cell metabolism and defense strategies has to be achieved during infection. On the bacterial side, many operons responsible for iron acquisition and scavenging have been described. However, much less is known how the host cell modulates its iron homeostasis and how pathogens might actively influence such homeostasis.

\section{Results}

\section{Transferrin receptor is required for Francisella} intracellular proliferation but not for Salmonella In order to determine if expression of TfR 1 is required for proliferation of Francisella and Salmonella inside macrophages, siRNA was used to silence the expression of TfR1 in murine macrophages (RAW264.7). Expression of the transferrin receptor was suppressed significantly $48 \mathrm{~h}$ after transfection with siRNA as measured by fluorescence microscopy and immunoblotting (Figure $1 \mathrm{~A}$ and $1 \mathrm{~B})$. Our transfection efficiency for siRNA was $63 \%(+/-7 \%)$, which was determined by counting cells, which had taken up siRNA labeled with the red fluorescence dye Alexa Fluor 555 (Figure 1A). Transfected cells
A
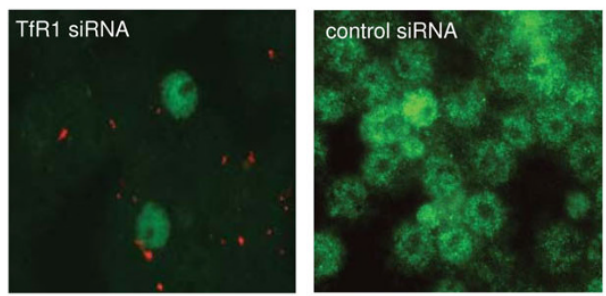

B

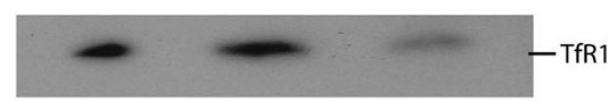

C
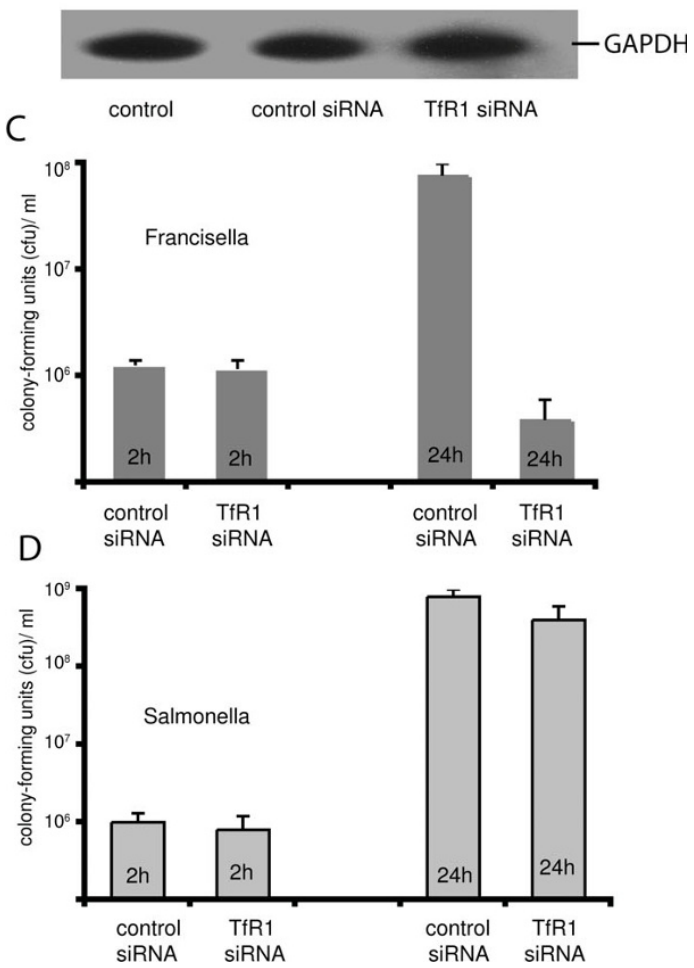

Figure 1 Francisella, but not Salmonella requires TfR1 for proliferation inside macrophages. A. RAW264.7 macrophages were transfected with siRNA (coupled to Alexa Fluor 555, red fluorescence) specific for TfR1 or as control with random siRNA (no red fluorescence). After $48 \mathrm{~h}$ cells were fixed and processed for immunofluorescence with a mouse anti-TfR1 antibody followed by an Alexa488 conjugated goat-anti-mouse lgG (green fluorescence). Overlay of both fluorescence channels is shown. B. Proteins were solubilized from transfected and infected cells as above, separated on a 9\% SDS-PAGE, transferred to Westran membranes, and immunoblotted with antiserum to TfR1. Visualization was by chemiluminescence C. RAW264.7 macrophages were transfected with TfR1-siRNA or with random siRNA (control). $48 \mathrm{~h}$ cells after transfection cells were infected with Francisella for $2 \mathrm{~h}$ or $24 \mathrm{~h}$. The number of intracellular bacteria was obtained by plating a lysate of the host cells on chocolate agar plates for colony-forming units (cfus). Means of triplicate experiments $+/-1$ standard error of mean are shown. D. RAW264.7 cells were treated as in $C$ and then infected with Salmonella for $2 \mathrm{~h}$ or $24 \mathrm{~h}$. The number of intracellular bacteria was determined as in C. Means of triplicate experiments +/1 standard error of mean are shown. 
appear to have an almost complete reduction of TfR1 (Figure 1A). Thus, the residual expression of transferrin receptors seen by immunoblot (Figure 1B) is most likely due to non-transfected cells.

Macrophages (RAW264.7) transfected with TfR1siRNA were infected with Francisella tularensis subspecies holarctica vaccine strain (F. tularensis LVS) or wildtype Salmonella typhimurium (ATTC 14208). F. tularensis LVS has been developed from fully virulent type B Francisella strains. It is attenuated in humans, but virulent in a mouse model [24]. After two hours of infection, there was no difference in the number of intracellular Salmonella $(\mathrm{p}=0.91)$ or Francisella $(\mathrm{p}=$ 0.89 ) between non-transfected and transfected macrophages (Figure $1 \mathrm{C}$ and 1D). This suggests that expression of TfR1 does not affect bacterial entry processes. Francisella, however, failed to proliferate in macrophages in which expression of the transferrin receptor was suppressed (Figure 1C; $\mathrm{p}=0.005$ ). The amount of Francisella recovered after $24 \mathrm{~h}$ most likely represents growth in macrophages which could not be transfected with siRNA. In contrast, intracellular proliferation of $S$. typhimurium was not affected by the lack of TfR1 (Figure 1D; $\mathrm{p}=0.89$ ). Addition of lactoferrin - chelated iron (Fe content $>0.15 \% \mathrm{w} / \mathrm{w}$, final lactoferrin concentration of $0.01 \mathrm{mg} / \mathrm{ml}$ ) as external iron source to macrophages with suppressed TfR1 rescued the proliferation of Francisella at intermediate levels (data not shown).

\section{Spatial relationship of transferrin receptor and Francisella-containing vacuole}

Some intracellular pathogens have devised ways to attract transferrin receptors to the intracellular vesicles they reside in [11]. When Salmonella enters macrophages, it localizes to an early endosome that is characterized by EEA1 and recruitment of the transferrin receptor (TfR1). As the Salmonella-containing vacuole matures and acquires markers of late endosomes (Rab7, Rab9), it also loses TfR1 [25,26].

Francisella differs from Salmonella by escaping early during infection from its endosomal environment. Since little is known about TfR 1 in macrophages infected with Francisella, we investigated the role of the transferrin receptor during infection and its relation to the maturation of the Francisella-containing vacuole (FCV). Murine macrophages (RAW264.7) were infected with Francisella LVS that constitutively expressed Gfp. At defined time intervals, infected cells were fixed and prepared for immunostaining. This demonstrated that early during entry (15 and 30 minutes after infection), there is significant co-localization of FCV and TfR1 (Figure 2A and 2E). As Francisella is trafficking away from the cell membrane during the time course of the infection, the co-localization with TfR 1 is lost (Figure $2 \mathrm{~B}$ and $2 \mathrm{E} ; \mathrm{p}=0.88$ for comparison of 15 and 30 minutes timepoints, $p=0.006$ for 30 and 45 minute timepoints, and $\mathrm{p}=0.61$ for 45 and 60 minute timepoints (Student's t-test).

Early recycling endosomes are characterized by carrying TfR1, EEA1, and Rab5, while excluding Rab7 unless they are destined for further trafficking along the lysosomal degradation pathway [27]. Macrophages infected with Francisella were stained with antisera to Rab5 and Rab7. This demonstrated that Francisella very early on at the membrane recruits Rab5 (Figure $2 \mathrm{C}$ and 2E; $\mathrm{p}=0.09$ for 15 and 30 minutes). Colocalization of Francisella and Rab5 decreases over time as Francisella escapes from the vacuole (Figure 2E; $\mathrm{p}=0.03$ for comparison of 30 and 45 minutes, $\mathrm{p}=0.83$ for 45 and 60 minutes, Student's t-test). However, there is no co-localization with Rab7-containing vesicles (Figure $2 \mathrm{D}$ and $2 \mathrm{E} ; \mathrm{p}=0.88$ for comparison of 15 and 30 minutes, $\mathrm{p}=0.91$ for 30 and 45 minutes, $\mathrm{p}=0.89$ for 45 and 60 minutes, Student's t-test).

These findings suggest that Francisella enters through an early endosome, which is characterized by carrying TfR1 and Rab5. The Francisella-containing vacuole does not mature further by acquiring Rab7 and does not retain TfR1. This is most likely due to exit from the vacuole [13] rather than to trafficking to a different vesicle environment with concomitant loss of TfR1.

\section{Infection of macrophages with Francisella upregulates transferrin receptor}

Expression of TfR1 remains unchanged during infection with wild-type Salmonella [28]. However, when expression of the transferrin receptor in uninfected macrophages was compared by microscopy to the expression in cells infected with Francisella, it became evident that Francisella-infected macrophages have a higher level of transferrin receptor expression (Figure 3A). This was confirmed by comparing the expression level of the transferrin receptor in Francisella-infected macrophages to the level found in uninfected cells by immunblotting at one hour and twenty-four hours after infection (Figure 3B). We also tested the expression level of transferrin receptor in cells, which had taken up formalin-fixed Francisella. This did not lead to a comparable upregulation of TfR1 (Figure 3B). Synthesis of the transferrin receptor is mainly regulated at the translational level as a response to the iron level or to other inputs. Indeed, after two hours of infection there was no increase in the mRNA level for Tfr 1 as determined by real-time RT-PCR (Figure 3C; $\mathrm{p}$ $=0.29$ ). However, after $24 \mathrm{~h}$ of infection, the mRNA level for TfR1 had more than doubled (Figure 3C; $\mathrm{p}=$ 0.002). 

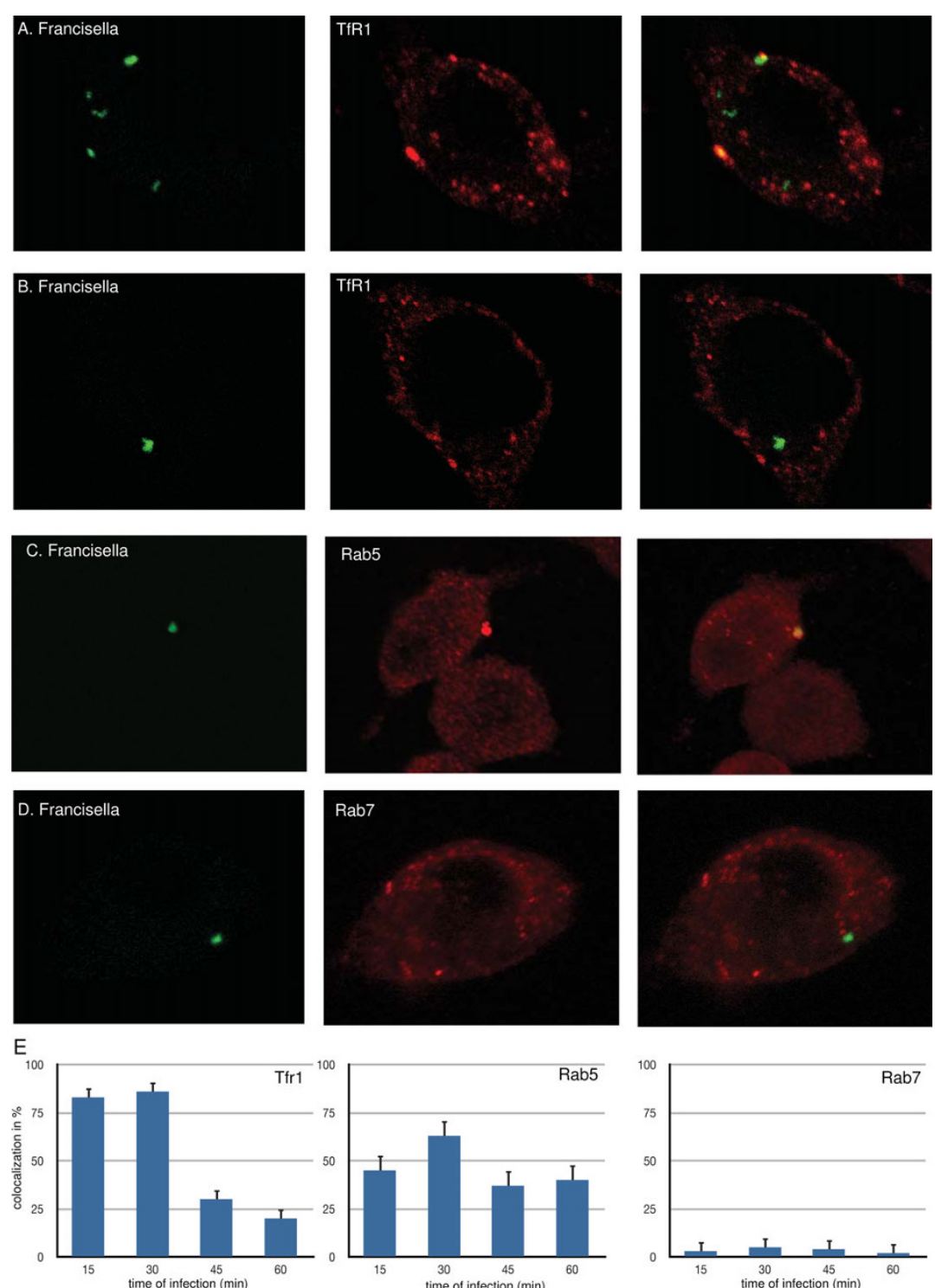

Figure 2 Transferrin receptor TfR1 and Rab5, but not Rab7, co-localize with Francisella. Macrophages (RAW264.7) were infected with Francisella that constitutively expressed green fluorescence protein (Gfp). At defined time intervals of infection, cells were fixed and stained with goat anti-TfR1 (A, B), with rabbit anti-Rab5 (C), or goat anti-Rab7 (D), followed by reaction with goat-anti-rabbit or rabbit-anti-goat lgG conjugated to Alexa594 (red fluorescence). Representative confocal images for thirty minutes of infection from twenty z-stacks acquired at 0.2 $\mu \mathrm{m}$ intervals are shown for each fluorescence channel, which were then merged using Volocity 4.1 software package (Improvision). E. The colocalization of Francisella with TfR1, Rab5, or Rab7 is described quantitatively for each time point by analyzing 100 infected cells from triplicate independent infection experiments. Means +/- 1 standard error of mean (SEM) are shown.

Increased level of transferrin receptor in infected cells can increase the labile iron pool

An increased TfR1 expression could translate into enhanced transferrin-mediated delivery of iron into the host cell and increased iron availability for Francisella. For Francisella, this could be accomplished by transferrin directly binding to the bacterial cell surface via a transferrin-binding protein, as has been described for other, mostly extracellular bacteria [20]. Search of the Francisella genome did not reveal any homologue to transferrin-binding proteins ((S.Daefler, unpublished observation). We could also experimentally verify that apo-transferrin and holotransferrin do not bind to Francisella (data not shown).

We therefore asked if the increased expression of TfR1 correlates with an increase of iron delivery to the host cell. In most cells, uptake of transferrin-bound iron leads to fast delivery into the cytosolic labile iron pool, which can be operationally defined as the cell chelatable pool that includes $\mathrm{Fe}^{2+}$ and $\mathrm{Fe}^{3+}$ associated with ligands 


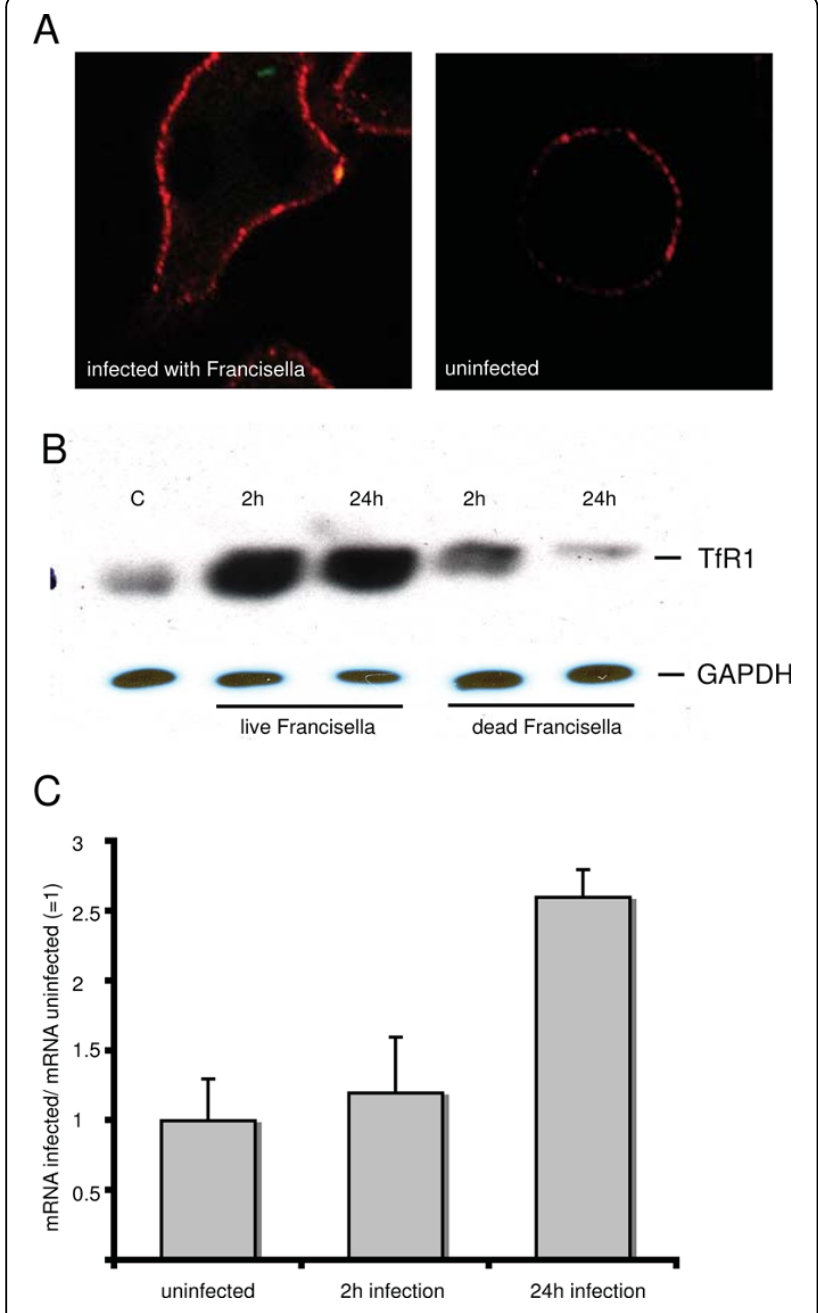

Figure 3 Infection with Francisella increases expression of transferrin receptor. A. RAW264.7 macrophages were infected with Francisella that constitutively expressed Gfp. After $2 \mathrm{~h}$ infected cells were fixed and processed for immunofluorescence with a mouse anti-TfR1 antibody followed by an Alexa594 conjugated goat-antimouse lgG (red fluorescence). Single confocal planes for merged fluorescence channels are shown. B. RAW264.7 cells were infected with live or formalin-inactivated Francisella (dead) for two and twenty-four hours. Immunoblotting of solubilized proteins was done with mouse anti-TfR1 and mouse anti-GAPDH as control. Visualization was by chemiluminescence. C. mRNA levels for TfR1 in RAW264.7 macrophages were determined after 2 or $24 \mathrm{~h}$ of infection with Francisella by quantitative light cycler PCR; levels are normalized to GAPDH-mRNA levels. Means of $n=6$ experiments +/1 standard error of mean (SEM) are shown.

such as organic anions, polypeptides, or surface membrane components [29]. The labile iron pool (LIP) composes the metabolically active and regulatory forms of iron [[29,30], Breuer et al., 2007, Int J Biochem Cell Biol]. A sensitive way to measure the labile iron pool without cell disruption is the use of a membrane permeable fluorescent probe such as calcein. Calcein rapidly forms a complex with iron in a 1:1 stoichiometry. This results in quenching of the green fluorescence of calcein. When cells are loaded so that there is a minor excess of free fluorescent calcein, an increase in the LIP will result in a decrease of the fluorescence signal [31], whereas the total cell-associated LIP can be determined after dequenching of the fluorescence signal with a cellpermeant Fe-chelator [29].

Macrophages were infected with Francisella for two and twenty-four hours or left uninfected as control. After loading with calcein, cells were exposed to holotransferrin as delivery vehicle for iron while the fluorescence signal was measured. In macrophages infected with Francisella, there is a rapid iron uptake as determined by the slope of the fluorescence quenching, which is steeper than in the control sample (uninfected cells) (Figure 4A, 4B, and 4D; $\mathrm{p}=0.0002$ for $2 \mathrm{~h}$ infection, $\mathrm{p}=0.002$ for $24 \mathrm{~h}$ infection, Student's t-test). Infected macrophages also appear to at least transiently increase the LIP more than uninfected cells, as evidenced by the amplitude of fluorescence quenching (Figure 4A, 4B, and $4 \mathrm{C} ; \mathrm{p}=0.003$ for $2 \mathrm{~h}$ infection, $\mathrm{p}=$ 0.001 for 24 h infection, Student's t-test). This observation is consistent with an increased number of TfRs on the cell surface, allowing an increased uptake at a faster rate of iron into the cell. The iron measured here is at least temporarily available as soluble iron and should thus be readily available for uptake by Francisella. In contrast, when we measured the LIP of macrophages whose TfR1 expression has been suppressed by siRNA, we found a decreased LIP (Figure $4 C ; \mathrm{p}=0.001$ ) and a decreased rate of iron uptake (Figure 4D; $\mathrm{p}=0.001$ ).

\section{Labile iron pool during infection with Francisella or Salmonella}

While increased expression of TfR 1 leads to an increase in the labile iron pool when exposed to iron-loaded transferrin, the overall labile iron pool (LIP) of the host cell can be affected in many different ways during infection. We therefore assessed the LIP during infection with Francisella by using the calcein method as described earlier [29] and compared it to the LIP during infection with Salmonella. After two hours of infection with Francisella and Salmonella there was a 10-25\% increase in the labile iron pool (Figure 5; p $=0.01$ for Francisella, $\mathrm{p}=0.002$ for Salmonella). Over the next twenty-two hours, macrophages infected with Francisella maintained an increased iron pool (Figure 5; p = 0.008 for $8 \mathrm{~h}, \mathrm{p}=0.002$ for $16 \mathrm{~h}$, and $\mathrm{p}=0.005$ for 24 h), whereas those infected with Salmonella showed a persistently decreasing iron pool (Figure 5; $\mathrm{p}=0.002$ for $8 \mathrm{~h}, \mathrm{p}=0.04$ for $16 \mathrm{~h}$, and $\mathrm{p}=0.03$ for $24 \mathrm{~h}$ ).

We also measured changes in the labile iron pool during infection with two isogenic mutant Salmonella strains, spiA and spiC, which have intracellular 
A

B
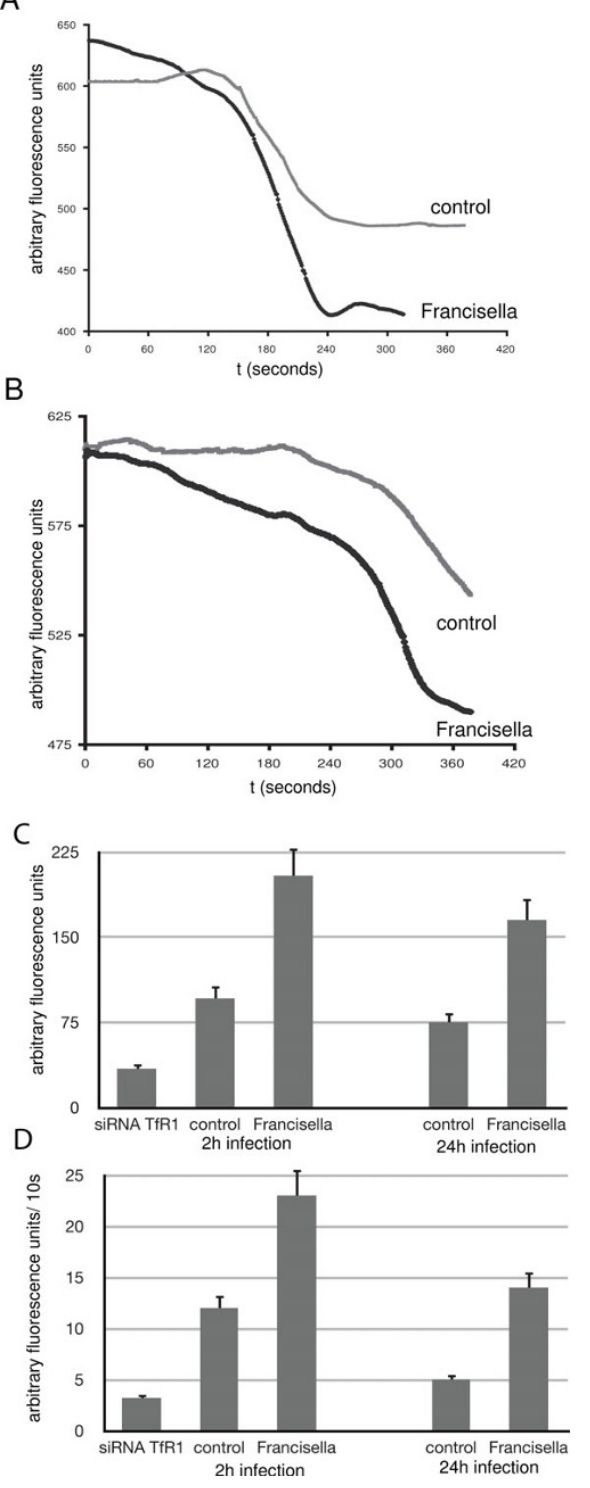

Figure 4 Transferrin-mediated delivery of iron increases the labile iron pool in Francisella-infected cells more efficiently than in uninfected cells. RAW macrophages were infected with Francisella LVS for $2 \mathrm{~h}$ (A) or $24 \mathrm{~h}$ (B) or left uninfected (control) and then loaded with Calcein-AM. The cell suspension was maintained at $37^{\circ} \mathrm{C}$ in a fluorometer. After stabilization of the fluorescence signal, holo-transferrin was added to the solution $(t=0)$ and the fluorescence signal recorded at one-second intervals. A decrease in the fluorescence indicates chelation of incoming iron with calcein, the amount of which is proportional to the slope and amplitude of the fluorescence signal. Results of triplicate measurements from triplicate experiments $(n=9)$ as described in A and B were analyzed for total amount of iron acquired as measured by arbitrary fluorescence units (C) and velocity of iron acquisition as measured by the change of fluorescence over time (D). Total iron and rate of iron uptake was also analyzed for macrophages whose TfR1 expression was suppressed by siRNA (siRNA TfR1 in Figure $4 C$ and 4D). Measurements were made $24 \mathrm{~h}$ after transfection of uninfected macrophages (RAW264.7) with siRNA. All Values are given as means +/- 1 standard error of mean (SEM).

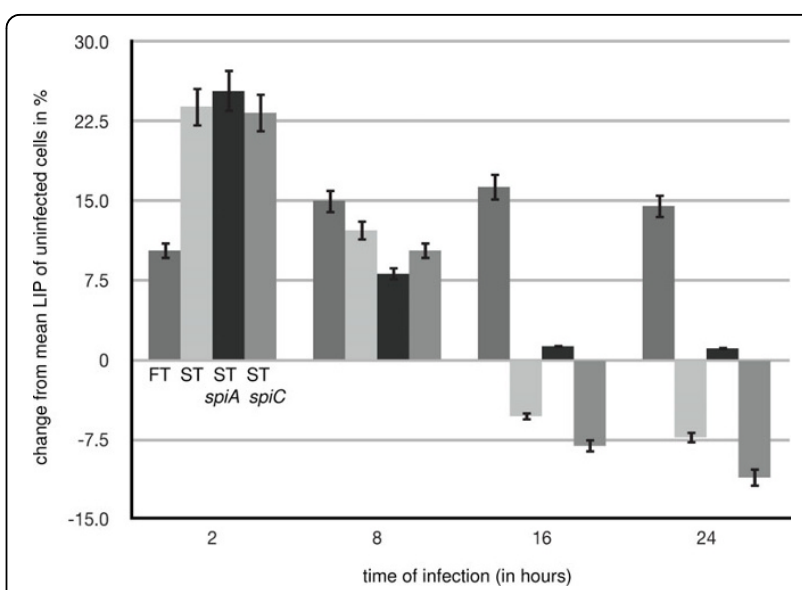

Figure 5 Labile iron pool in macrophages during infection with Francisella and Salmonella. RAW264.7 macrophages were infected for 2 h, 8 h, 16 h, and $24 \mathrm{~h}$ with wild Francisella (FT), wild-type Salmonella (ST), spiA Salmonella (ST/spiA), or spiC Salmonella (ST/ spiC). Labile iron pool was determined with the calcein method as described in detail in Materials and Methods. Measurements were in arbitrary fluorescence units standardized to uninfected samples. Data shown are the deviation in percentage from uninfected samples from triplicate experiments. Results are expressed as means $+/-1$ standard error of mean (SEM).

trafficking deficits associated with reduced intracellular proliferation and avirulence in mice. These strains carry two different deletions in the SPI-2 type III secretion system (spiA and spiC) [32,33]. The rationale for using these strains in our experiments was to investigate if different subcellular localizations of a given pathogen can lead to different patterns in iron acquisition. After two hours of infection, the labile iron pool was increased similar to macrophages infected with wild-type Salmonella (Figure 5; $\mathrm{p}=0.001$ for spiA Salmonella, $\mathrm{p}=0.002$ for spiC Salmonella). After twenty-four hours, spiC Salmonella gradually decreased the iron pool similar to infection with wild type (Figure $5 ; \mathrm{p}=0.02$ for $8 \mathrm{~h}, \mathrm{p}=$ 0.02 for $16 \mathrm{~h}, \mathrm{p}=0.001$ for $24 \mathrm{~h}$ ). In contrast, the labile iron pool initially decreased and then remained unchanged during infection with spiA Salmonella (Figure 5; $\mathrm{p}=0.02$ for $8 \mathrm{~h}, \mathrm{p}=0.45$ for $16 \mathrm{~h}, \mathrm{p}=0.56$ for $24 \mathrm{~h}$ ).

\section{Iron-related gene expression in macrophages infected with Salmonella or Francisella}

Acquisition of iron through TfR 1 requires expression of accessory gene products (Steap3, Dmt1) and can be countered by increased iron export (Fpn1) or scavenging of iron by the lipocalin system (Lcn2, LcnR). Induction of innate immune responses during infection can modulate iron homeostasis pathways through induction of hepcidin (Hamp1) and Lcn2. The expression of such genes and selected other genes that are involved in the 
homeostasis of host cell iron levels were investigated by real-time RT-PCR during infection with Francisella and compared to the expression profile of host cells during infection with Salmonella.

There are two main eukaryotic iron-regulatory proteins, IRP1 and IRP2, which sense changes in the labile iron pool and secondary signals associated with redox active species. They both act post-translationally by stabilizing their respective target mRNA and by affecting initiation of translation. While expression of IRP-2 is increased by Salmonella and Francisella ( $\mathrm{p}=0.003$ and $\mathrm{p}=0.002$ respectively), IRP1 is strongly induced only in Francisella-infected cells (Figure 6A and 6B; p $=0.0001$ for Francisella, $\mathrm{p}=0.02$ for Salmonella).

After uptake of iron via TfR1 and acidity-triggered release into the vesicle, ferric iron needs to be reduced, which is accomplished by the ferrireductase Steap3 [34]. After reduction, ferrous iron is transported into the cytosol by Dmt1 or functional Nramp1 [35,36]. There is a fivefold higher induction of Steap3 and Dmt1 during infection with Francisella ( $\mathrm{p}=0.0001$ ) when compared to infection with wild-type Salmonella $(\mathrm{p}=0.67)$ (Figure $6 \mathrm{~A}$ and $6 \mathrm{~B})$.

Infected host cells can restrict the intracellular iron pool available for intracellular parasites by transporting iron out of the cells via ferroportin 1 (Fpn1), a transmembrane iron efflux protein [37]. While Fpn1 is increased 2.5-fold in macrophages infected with Francisella $(\mathrm{p}=0.02)$, there is no change during infection with Salmonella $(\mathrm{p}=0.46)$ (Figure $5 \mathrm{~A}$ and $5 \mathrm{~B})$.

During infection with bacteria, hepatocytes secrete the antimicrobial peptide hepcidin (Hamp1), which binds to ferroportin on macrophages (and other cell types). This leads to internalization and degradation of ferroportin and entrapment of iron inside the cell. It was also shown recently that hepcidin is induced in myeloid cells through the TLR-4 pathway and regulates ferroportin levels at the transcriptional and post-translational level [38]. Hepcidin thus effectively reduces iron efflux [39-41]. There is a two-fold stronger induction of hepcidin during infection with Salmonella when compared to infection with Francisella (Figure 6A and 6B; $\mathrm{p}=0.001$ and $\mathrm{p}=0.01$ respectively). This might be explained by Francisella LPS preferentially stimulating the TLR-2 pathway, while Salmonella LPS induces the TLR-4 pathway [42].

The lipocalin system provides the host with another way of scavenging iron or withholding it from bacteria [43]. The host protein lipocalin (Lcn2) can interact with bacterial siderophores and has now been recognized as an important arm of the innate immune response after its production is stimulated by recognition of bacteria through TLR-4 pathways [44]. Lcn2 is induced twofold in cells infected with Francisella $(\mathrm{p}=0.01)$, but more than 15-fold when cells are infected with Salmonella (p
$=0.002)$. This might again be expected because of the strong induction of the TLR-4 pathway by Salmonella in comparison to the preferred TLR-2 induction by Francisella. Salmonella, however, do not raise mRNA levels for the lipocalin receptor (LcnR), which are significantly increased in Francisella-infected macrophages (Figure 6A and 6B).

Heme oxygenase (HO-1, Hmox1) catalyzes the conversion of heme to biliverdin, iron, and carbon monoxide. In macrophages it has an important antioxidative protective function, presumably by reducing pro-oxidant or pro-apoptotic hemoproteins $[45,46]$. Not unexpectedly, the mRNA level for Hmox1 is increased in macrophages infected by Francisella and Salmonella (Figure $6 \mathrm{~A}$ and $6 \mathrm{~B} ; \mathrm{p}=0.002$ and $\mathrm{p}=0.002$ respectively).

None of the components of the ferritin iron storage system are affected by infection with Salmonella or Francisella as measured by determining the expression of Fth1 and Ftl1 (Figure 6A and 6B; $\mathrm{p}=0.91$ and $\mathrm{p}=$ 0.90 for Francisella and $\mathrm{p}=0.88$ and $\mathrm{p}=0.78$ for Salmonella).

These gene-expression data suggest that Francisella drives a more active transferrin-mediated iron uptake program than Salmonella. Increased mRNA levels for IRP1 and IRP2 maintain increased translational levels for TfR1. Induction of genes required for transfer of iron to the cytosol via Dmt1 and Steap3 support the TfR1-mediated import route. Preferential induction of the TLR-4 pathway by Salmonella leads to a strong induction of hepcidin and lipocalin.

We further sought to characterize the expression profile of these iron-homoestasis-related genes in the spiC and spiA Salmonella mutants, which lead to variable alterations in the LIP (Figure 5). Both mutant strains have a higher increase in the Steap3/DMT1 genes than wild-type Salmonella $(\mathrm{p}=0.01$ and $\mathrm{p}=0.001$ for spiA Salmonella, and $\mathrm{p}=0.01$ and $\mathrm{p}=0.003$ for spiC Salmonella), while the induction of the iron-regulatory proteins IRP1 and IRP2 are lower ( $\mathrm{p}=0.02$ for IRP1 and $\mathrm{p}=0.02$ for IRP2 in spiA Salmonella $\mathrm{p}=0.35$ for IRP1 and $\mathrm{p}=0.02$ for IRP2 in spiC Salmonella). While TLR-4 driven induction of lipocalin is maintained in the mutant strains $(\mathrm{p}=0.002$ for spiA and $\mathrm{p}=0.001$ for spiC Salmonella), there is no induction of hepcidin ( $\mathrm{p}=$ 0.89 and $\mathrm{p}=0.78$ respectively). The iron exporter Fpn1 is increased threefold in the spiC mutant $(\mathrm{p}=0.01)$, while there is no increase in the $\operatorname{spiA}$ mutant $(\mathrm{p}=0.78)$ (Figure 6C and 6D). This might be one possible explanation for the decrease in the labile iron pool in the spiC mutant in comparison to the spiA mutant (Figure 5 ). These findings suggest that distinct bacterial gene mutations with associated aberrant intracellular trafficking can affect the expression of iron homeostasis genes in the host cell. 

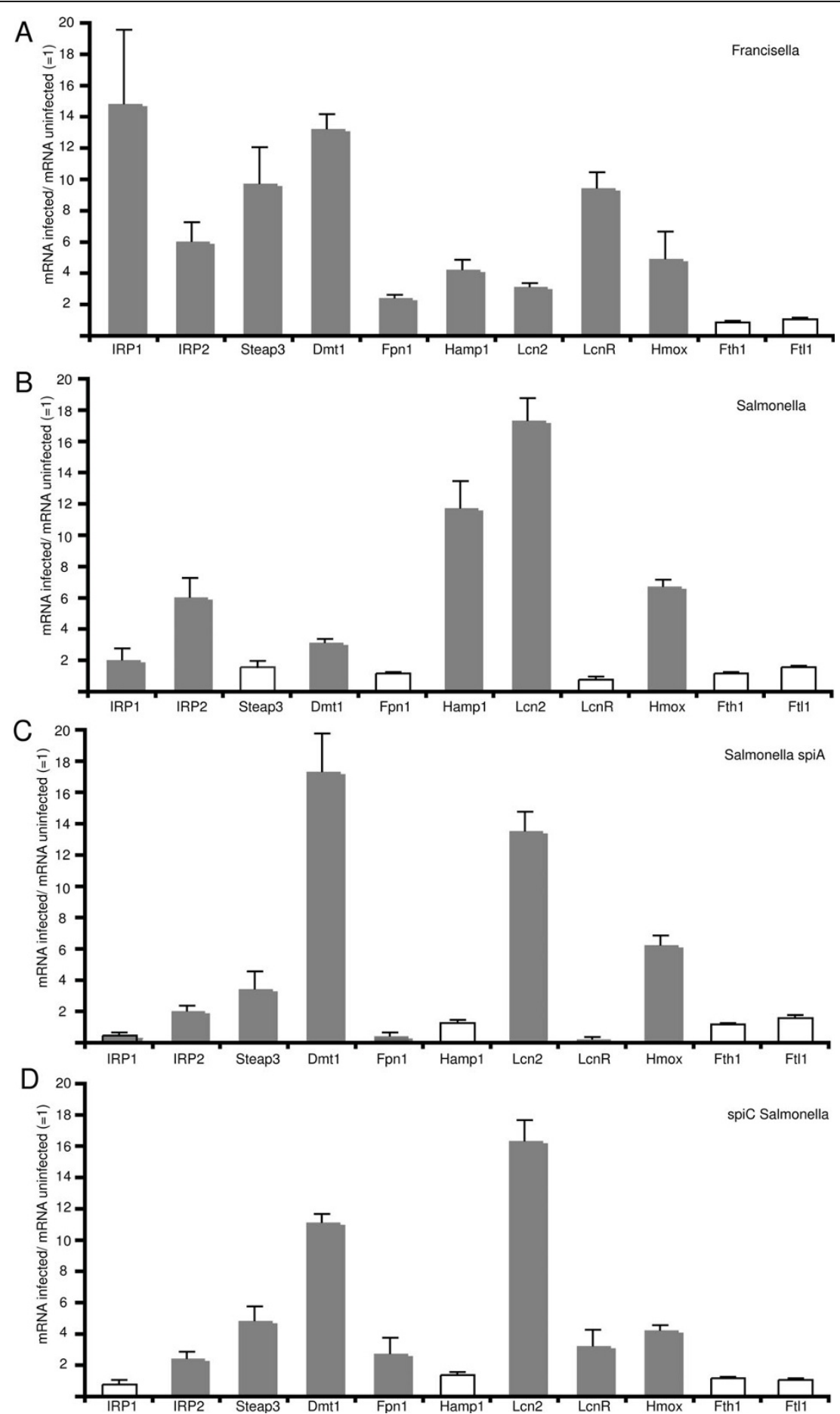

Figure 6 Expression of genes involved in iron homeostasis during infection with Francisella or Salmonella. RAW264.7 macrophages were infected for $24 \mathrm{~h}$ with wild-type Francisella (A), wild type Salmonella (B), spiC Salmonella (C), or spiA Salmonella (D). Quantitative mRNA levels were determined by quantitative light cycler PCR for: iron-regulatory protein 1 (IRP1), iron regulatory protein 2 (IRP2), ferrireductase (Steap3), transmembrane iron transporter (Dmt1), lipocalin (Lcn2), lipocalin receptor (LcnR), ferroportin (Fpn1), antimicrobial peptide hepcidin (Hamp1), heme oxygenase (Hmox1), ferritin heavy chain 1(Fth1), ferritin light chain 1 (Ftl1), and ferritin light chain 2 (Ftl2). Measurements were standardized to GAPDH-mRNA levels for each experiment. Values shown represent the ratio of mRNA for a given gene in infected cells divided by the mRNA level in uninfected cells (mRNA infected/mRNA uninfected). Statistically significant expression data are shown by solid bars (Student's t-test, $\mathrm{p}<0.05$ is considered as significant; individual $\mathrm{p}$-values are given in the text). Results from $\mathrm{n}=6$ experiments are expressed as means $+/-1$ standard error of mean (SEM). 


\section{Discussion}

We have characterized two different phenotypes of host cell and intracellular bacterial pathogen behavior in relation to host cell iron metabolism and bacterial iron requirements. Francisella drives an active iron acquisition program through the transferrin receptor TfR1 with a sustained increase in the host cell labile iron pool. Since Francisella depends on expression of TfR1 for intracellular survival, it might need an increased host cell iron level for its own metabolism and might be able to efficiently counteract increased production of host cell reactive redox species. Salmonella, on the other hand, does not require TfR 1 for growth inside its host cell, lacks a strong induction of gene products aimed at facilitating iron import via TfR1, and negotiates a decreased iron level in the host cell. This might be explained by Salmonella's intracellular localization within an endosomal structure or perhaps by more efficient iron acquisition strategies. The distinction of these two phenotypes will allow further characterization and understanding of eukaryotic iron metabolism and its modulation by intracellular bacteria.

Francisella enters macrophages inside an early endosome, from which it later escapes into the cell cytosol [13]. We have provided corroborating evidence that entry occurs in an early endosome with recruitment of TfR1 and Rab5, but no acquisition of Rab7, which is a prerequisite for further maturation in the phagolysosomal trafficking pathway. In this study we have demonstrated a very early co-localization of TfR 1 and Francisella at the cell surface. This suggests that TfR1 is recruited during the entry process rather than by successive fusion of Francisella-containing vesicles with TfR1-carrying endosomes. Such a process differs from $M$. tuberculosis-containing vesicles, which recruit TfR through endosome fusions during infection of the host cell [11].

Increased expression of the transferrin receptor has been shown previously during infection with Ehrlichia, Chlamydia, and Coxiella, while reduced or unaltered expression was observed during infection with Salmonella and Legionella $[28,47]$ as a means of host defense by restricting the iron available for the invading pathogen. In fact, decreased expression of TfR1 in a patient due to a chronic inflammatory condition (with increased IFN- $\gamma$ production) proved non-permissive for infection with Legionella [48]. Infection with Ehrlichia chafeensis and E. sennetsu changes the binding affinities for IRP-1 during the first hours of infection with a concomitant increase in levels of transferrin receptor. This is followed by a response at the transcriptional level of transferrin receptor mRNA at $24 \mathrm{~h}$ of infection [10]. Similar to our observations with Francisella, these effects require viable
Ehrlichia and cannot be caused by the Human Granulocytic Ehrlichiosis Agent. While Francisella shows a very early and intense colocalization with $\mathrm{TfR}$ and then escapes from the vesicle, Ehrlichia remains in a membranous compartment, which is characterized by Rab5 and EEA1 and only over time recruits TfR1 [49]. While our studies did not address the mechanisms by which Francisella increases the expression of TfR1, we speculate that a disruption of the host cell home iron homeostasis system causes the cell to sense a low iron balance with subsequent initiation of an active iron acquisition program. We cannot rule out that some bacterial product directly or indirectly through intermediates of inflammation affects IRP-1 binding affinities or that other yet uncharacterized cytokine activation pathway triggered by the infection play a role.

While it is known that TfR1 transports Fe-loaded transferrin to the bacterium-containing vesicle, it is not at all clear that iron delivered in this way can be utilized by bacteria. For M. tuberculosis it could be demonstrated that Fe delivered by transferrin can be utilized [50]. Based on the kinetics of Fe delivery it was calculated, however, that at least a portion of the Fe delivered by transferrin is first delivered to the cytosol, presumably through the action of DMT1 [51]. While siderophores clearly play a role, it could also be demonstrated that these exochelins cannot directly remove Fe from transferrin [52]. It has also not been shown if such siderophores could actually transverse the endosome membrane. Our data demonstrate that Francisella actively upregulates TfR1, which leads to an improved delivery of iron into the labile intracellular iron pool. In contrast to Salmonella, Francisella also drives an active iron acquisition program with upregulation of accessory iron metabolic genes such as the iron transporter Dmt1 and the ferrireductase Steap3, which all serve to promote the import of iron from TfR1 to the cytosol. We propose that Francisella can directly exploit the concomitant increase in LIP during infection, whereas such an increase would be of little benefit to Salmonella with a preferentially endosomal location.

A recent study has examined the expression profile of selected iron-homeiostasis genes and iron-loading of ferritin in murine macrophages during infection with Salmonella [28]. While their findings agree with ours with regard to the upregulation of Lcn2, Hmox1, and Hamp, the authors could not find a significant increase in Dmt1, but did see an increase in Fpn1. This correlated with their observation of increased iron efflux from infected cells and decreased iron content of ferritin. Some of the differences between our data and theirs might be explained by their use of a particular Salmonella strain (C5RP4). Of particular interest in this 
context is that the spiC Salmonella mutant strain used in our studies behaves quite similiar to the C5RP4 strain by demonstrating an increase in Fpn1 (Figure 6D). It is thus conceivable that the Salmonella strain employed by Nairz and colleagues carries distinct uncharacterized gene mutations or phenotypes. Our assessment of the labile iron pool after infection with Salmonella after $24 \mathrm{~h}$ shows a decrease (Figure 5) and agrees with the findings reported by Nairz [28].

\section{Conclusions}

Iron acquisition and utilization by microbes is of critical importance for bacterial pathogenesis. Defects in the bacterium's ability to efficiently scavenge iron and use it in its metabolism usually lead to avirulence. However, little is known how bacteria might modulate the iron handling properties of their host cells.

We identified two distinct iron-handling scenarios for two different bacterial pathogens. Francisella tularensis drives an active iron acquisition program via the TfR1 pathway program with induction of ferrireductase (Steap3), iron membrane transporter Dmt1, and iron regulatory proteins IRP1 and IRP2, which is associated with a sustained increase of the labile iron pool inside the macrophage. Expression of TfR1 is critical for Francisella's intracellular proliferation. This contrasts with infection of macrophages by wild-type Salmonella typhimurium, which does not require expression of TfR1 for successful intracellular survival. Macrophages infected with Salmonella lack significant induction of Dmt1, Steap3, and IRP1, and maintain their labile iron pool at normal levels.

\section{Methods}

Bacterial strains, cell lines, growth conditions, and plasmids

Francisella tularensis subspecies holarctica vaccine strain (F. tularensis LVS, army lot 11) was generously provided to us by Dr. Karen Elkins (FDA). F. tularensis LVS was transformed with plasmid pFNLTP6 gro-gfp to produce a Francisella strain constitutively expressing green fluorescent protein (SD833). Wild-type Salmonella strain ATCC 14028 was used. Salmonella mutant strains spiC:: kan (EG10128) and spiA::kan (EG5793) are isogenic derivatives [32]. Francisella was grown on chocolate II agar enriched with IsoVitaleX (BD Biosciences, San Jose, $\mathrm{CA}$ ) for $40-48 \mathrm{hrs}$ at $37^{\circ} \mathrm{C}$. For liquid medium, we used Mueller-Hinton broth supplemented with IsoVitaleX. Salmonella strains and E.coli XL-1 were grown at $37^{\circ} \mathrm{C}$ with shaking in LB broth without glucose or on LB plates [53]. When indicated antibiotics were present (in $\mu \mathrm{g} / \mathrm{ml}$ ) at: kanamycin, 50; chloramphenicol, 50; for Francisella, kanamycin was used at $10 \mu \mathrm{g} / \mathrm{ml}$.

RAW264.7 murine macrophages were obtained from ATCC (TIB-71). Dulbecco's Modification of Eagle's
Medium (DMEM; Cellgro) was supplemented with 10\% fetal bovine serum (Hyclone, not heat-inactivated) and penicillin (100 I.U./ml) and streptomycin $(100 \mu \mathrm{g} / \mathrm{ml})$. When cells were used for Francisella infection assays, no antibiotics were added $24 \mathrm{~h}$ prior to infection. Cells were grown at $37^{\circ} \mathrm{C}$ and $5 \% \mathrm{CO} 2$.

A shuttle plasmid which encodes Gfp under the control of the groE promoter (pFNLTP6 gro-gfp) was kindly provided to us by Dr. Zahrt [54]. It carries a kanamycin antibiotic resistance marker.

\section{Infection Assay}

Several colonies of F. tularensis LVS were collected, washed twice with sterile phosphate buffer at $\mathrm{pH} 7.0$ (PBS, Mediatech Inc \#46-013-CM), and dispersed in cell culture complete medium for 15 minutes. Multiplicity of infection was adjusted to 10 using a standardized calibration curve of $\mathrm{OD}_{600} /$ colony-forming units (cfu). Bacteria were added to host cells at $60-80 \%$ confluency in 12-well dishes. At a given timepoint after the infection, host cells were washed repeatedly with warm PBS. If indicated, remaining extra-cellular bacteria were killed by the addition of $10 \mu \mathrm{g} / \mathrm{ml}$ of gentamicin to DMEM $\left(37^{\circ} \mathrm{C}, 5 \% \mathrm{CO} 2\right)$ for 60 minutes. Time points given in the text for infection include this 60 minute time period of culture in the presence of gentamicin, except when infected cells were processed for immunostaining. Gentamicin was removed by washing in DMEM. Infected cells were resuspended in complete tissue culture medium without addition of antibiotics. After a given time of infection, cells were lyzed in $0.5 \% \mathrm{~N}$-octyl $\beta$-glucopyranoside (Bioscience). Serial dilutions of cell lysates were plated on Chocolate II agar and incubated at $37^{\circ} \mathrm{C}$ for at two days. Infection with Salmonella was performed as described [55]. Comparison of infection results were analyzed by the Student's t-test, $\mathrm{p}<0.05$ was considered significant.

\section{Immunostaining}

Macrophage cell lines were grown on sterile coverslips in Petri dishes (6- or 12-well plates). Cells were infected with Francisella as described above, except that the step of killing extracellular bacteria with gentamicin was substituted by washing of adherent cells with DMEM three times. At indicated time points, cells on coverslips were fixed in $4 \%$ paraformaldehyde solution (Polysciences, \#18814) for 10 minutes, washed with PBS and permeabilized in $0.1 \%$ Triton $\times 100$ (Shelton Scientific IB07100) in PBS for 15 minutes. Reaction with antisera was performed in $0.05 \%$ TWEEN20/PBS for one hour at room temperature. Stained and dried coverslips were mounted on glass slide using Gold antifade medium (Invitrogen, \#P36930) and sealed with nail polish 
Antiserum to TfR1 was goat polyclonal IgG (SantaCruz sc 7087), to Rab5, rabbit polyclonal IgG (Santa Cruz SC-309) and to Rab7, goat polyclonal IgG (SC11303). Antibodies were used at a dilution of 1:500. Visualization was with staining with a goat-anti-rabbit or rabbit-anti-goat IgG conjugated to Alexa 594 (Invitrogen).

\section{Microscopy}

A Leica AOBS laser scanning microscope was used for all fluorescence microscopy. Images were acquired using Leica software. Analyses of images was with Volocity software (Volocity 4.1 Imporvision Inc., Lexington, MA). Overlap of individual fluorescence pixels from separate channels for each optical plane was determined with the Volocity 4.1 colocalization module. When results were quantified, 100 cells from randomly selected fields were evaluated. All cells found in a given field were analyzed, except for cells with obvious signs of cell death (detachment, ballooning), which were excluded (in general < $5 \%$ ). Results are reported as the percentage of 100 cells analyzed. Groupwise comparison was made by the Student's t-test, $\mathrm{p}<0.05$ was considered significant.

\section{RNA interference}

Two siRNAs for TfR1 (Tfrc_4 (TACCCATGACGTTGAATTGAA), and Tfrc_1 (ATCGTTAGTATCTAACATGAA)) were designed using proprietary software and synthesized. Both had 3' modifications with Alexa Fluor 555. Transfection of macrophages was accomplished with Lipofectamine 2000 according to the manufacturer's instruction. Only Tfrc1 had significant activity (data not shown) and was used for all further studies

\section{Real-time RT-PCR}

Total RNA was isolated and digested with DNAse using the Microto-Midi Total RNA Purification System
(Invitrogen, catalog no. 12183-018) according to the product instructions. RNA concentrations were determined by a RiboGreen assay (Molecular Probes, Carlsbad, CA; catalog no. R11490). Primer design was performed with the eXpress Profiling Suite software (Beckman) and mRNA sequences from the GenBank database. Uniqueness and specificity of each primer was verified using the Basic Local Alignment Search Tool http://www.ncbi.nlm.nih.gov/blast returning Genbank accession numbers. Primers are listed in Table 1.

The reverse transcription reactions were carried out with 20 units of Moloney Murine Leukemia Virus (MMuLV) reverse transcriptase (Fisher Scientific, catalog no. BP3208-1), 20 units RNase inhibitor (Fisher Scientific, catalog no. BP3225-1), RT-PCR buffer containing 10 $\mathrm{mM}$ Tris- $\mathrm{HCl}$ and $50 \mathrm{mM} \mathrm{KCl} ; 2.5 \mathrm{mM} \mathrm{MgCl} ; 10 \mathrm{mM}$ dithiothreitol; and $1 \mathrm{mM}$ of each dNTP. The concentration of each reverse primer was $5 \mu \mathrm{M}$. $100 \mathrm{ng}$ of total RNA from each sample was reverse transcribed using reverse primers. The reverse transcription reactions were incubated for $1 \mathrm{~min}$ at $48^{\circ} \mathrm{C}, 5 \mathrm{~min}$ at $37^{\circ} \mathrm{C}$, $60 \mathrm{~min}$ at $42^{\circ} \mathrm{C}$, and then $5 \mathrm{~min}$ at $95^{\circ} \mathrm{C}$.

Real-time RT-PCR was based on the high affinity, double-stranded DNA-binding dye SYBR Green using a Bio-Rad IQ SYBR Green Supermix according to manufacturer's instructions. A total of $2 \mu \mathrm{l}$ of cDNA was used in the qPCR reactions $(1 \times$ SYBR green PCR master mix, $500 \mathrm{nM}$ gene specific forward and reverse primers). All qPCR reactions started with $2 \mathrm{~min}$ at $95^{\circ} \mathrm{C}$ followed by 40 cycles of $15 \mathrm{~s}$ at $94^{\circ} \mathrm{C}$ and $20 \mathrm{~s}$ at $55^{\circ} \mathrm{C}$ and $30 \mathrm{~s}$ at $72^{\circ} \mathrm{C}$ in an Applied Biosystems $7900 \mathrm{HT}$ Fast RealTime PCR System. Differences in mRNA concentrations were quantified by the cycles to fluorescence midpoint cycle threshold calculation (2- $\Delta \mathrm{Ct}$ experimental gene$\Delta \mathrm{Ct}$ housekeeping gene]), using GAPDH as the housekeeping gene. Comparisons between two groups were performed with Statview 9.1.3 statistical analysis

Table 1 Primers used for real-time RT PCR

\begin{tabular}{|c|c|c|c|}
\hline Gene & Accession number & Forward primer $\left(5^{\prime} \rightarrow 3^{\prime}\right)$ & Reverse Primer $\left(5^{\prime} \rightarrow 3^{\prime}\right)$ \\
\hline GAPDH & NM_008084 & AGGTGACACTATAGAATACCCACTAACATCAAATGGGG & GTACGACTCACTATAGGGACCTTCCACAATGCCAAAGTT \\
\hline IRP1 & NM_007386 & AGGTGACACTATAGAATAACTTTGAAAGCTGCCTTGGA & GTACGACTCACTATAGGGACTCCACTTCCAGGAGACAGG \\
\hline IRP2 & NM_022655 & AGGTGACACTATAGAATATGAAGAAACGGACCTGCTCT & GTACGACTCACTATAGGGAGCTCACATCCAACCACCTCT \\
\hline TfR1 & BC054522 & AGGTGACACTATAGAATATGCAGAAAAGGTTGCAAATG & GTACGACTCACTATAGGGATGAGCATGTCCAAAGAGTGC \\
\hline Dmt1 & JM_008732 & AGGTGACACTATAGAATAGCCAGCCAGTAAGTTCAAGG & GTACGACTCACTATAGGGAGCTGTCCAGGAAGACCTGAG \\
\hline LenR & NM_021551 & AGGTGACACTATAGAATAGCAAGGCTACCCCATACAAA & GTACGACTCACTATAGGGAAAGAGCGAGGTCTGGGAAAT \\
\hline $\operatorname{Lcn} 2$ & NM_008491 & AGGTGACACTATAGAATACTGAATGGGTGGTGAGTGTG & GTACGACTCACTATAGGGATATTCAGCAGAAAGGGGACG \\
\hline Steap3 & BC037435 & AGGTGACACTATAGAATACTCTCTGTGCAGTCTCGCTG & GTACGACTCACTATAGGGATGCAGAGATGACGTTGAAGG \\
\hline Hmox1 & NM_010442 & AGGTGACACTATAGAATACCTCACTGGCAGGAAATCAT & GTACGACTCACTATAGGGACCAGAGTGTTCATTCGAGCA \\
\hline Fpn1 & AF226613 & AGGTGACACTATAGAATATGCCTTAGTTGTCCTITGGG & GTACGACTCACTATAGGGAGTGGAGAGAGAGTGGCCAAG \\
\hline Hamp1 & NM_032541 & AGGTGACACTATAGAATAGAGAGACACCAACTTCCCCA & GTACGACTCACTATAGGGATCAGGATGTGGCTCTAGGCT \\
\hline $\mathrm{Ftl} 1$ & NM_010240 & AGGTGACACTATAGAATAAAGATGGGCAACCATCTGAC & GTACGACTCACTATAGGGAGCCTCCTAGTCGTGCTTGAG \\
\hline Fth1 & NM_010239 & AGGTGACACTATAGAATACTCATGAGGAGAGGGAGCAT & GTACGACTCACTATAGGGAGTGCACACTCCATTGCATTC \\
\hline
\end{tabular}


software using the Student's t-test. $\mathrm{P}<0.05$ was considered statistically significant. All results are expressed as means +/- 1 standard error of the mean (SEM).

\section{Determination of the labile iron pool with calcein-AM}

Relative alterations in the levels of "labile iron pool" (LIP) by the upregulated transferrin receptors during the infection of Francisella in macrophages were determined with the fluorescent metalosensor calcein-AM $[29,56]$. Infection of RAW 264.7 macrophages with Francisella was carried at the MOI of 10 . After $1 \mathrm{hr}$ and $24 \mathrm{hrs}$ of infection cells were detached from plates using a rubber policeman and used in suspension. Uninfected controls were maintained as well.

A total of $5.5 \times 10^{6}$ infected macrophages were washed three times with warm DMEM. The cells were suspended in DMEM and then incubated with 0.125 $\mu \mathrm{M}$ calcein-AM (Invitrogen, \#C3100MP) for $10 \mathrm{~min}$ at $37^{\circ} \mathrm{C}$. After three washes with warm PBS to remove unbound calcein, the cells were resuspended in warm PBS. $200 \mu \mathrm{l}\left(5 \times 10^{4}\right)$ of calcein-loaded cells were suspended in a $5 \times 13 \mathrm{~mm}$ glass cuvette (Wheaton, Milleville, NJ \#225350). Fluorescence was monitored on a TD700 Fluorimeter (Turner Designs, Sunnyvale, CA) (488-nm excitation and $517-\mathrm{nm}$ emission) at $37^{\circ} \mathrm{C}$. After stabilization of the signal, $10 \mu \mathrm{g} / \mathrm{ml}$ of holo-transferrin (Sigma, \#T1283) was added to measure the changes in the intracellular calcein-bound iron pool of the infected cells. Fluorescent units were measured at one-second intervals. For comparative determination of the total cellular LIP, infected and uninfected macrophages were loaded with calcein-AM as above. Fluorescence (F) was measured exactly ten minutes after loading with calceinAM in a TD700 fluorimeter. A cell permeable Fe-chelator was added as described (16, [29]. Dequenched fluorescence $(\Delta \mathrm{F})$ was again determined 5 minutes after addition of deferrioxamine. Both values, $\mathrm{F}$ and $\Delta \mathrm{F}$, showed a linear correlation and represent the relative total macrophage LIP.

\section{Acknowledgements}

We thank Dr. K. Elkins for providing Francisella LVS strain and Dr. T. Zahrt for plasmid pFNLTP6 gro-gfp. This study was supported by U.S. Public Health Service grant POAI55637.

\section{Author details}

'Mount Sinai School of Medicine, One Gustave Levy Place, New York, NY 10570, USA. ${ }^{2}$ UTSW Medical Center at Dallas, Department of Microbiology, Dallas, TX, USA.

\section{Authors' contributions}

$X P$ and BT performed experiments and analyzed data, SD designed experiments, analyzed data, and drafted manuscript, EH provided critical guidance, insights, and suggestions. All authors read and approved the final manuscript.
Received: 13 November 2009

Accepted: 25 February 2010 Published: 25 February 2010

\section{References}

1. Radtke $A L, O^{\prime}$ Riordan $M X$ : Intracellular innate resistance to bacterial pathogens. Cell Microbiol 2006, 8:1720-1729.

2. Paradkar P, De Domenico I, Durchfort N, Zohn I, Kaplan J, Ward DM: Irondepletion limits intracellular bacterial growth in macrophages. Blood 2008, 112:866-874

3. Collins HL: The role of iron in infections with intracellular bacteria. Immunol Lett 2003, 85:193-195.

4. Chlosta S, Fishman DS, Harrington L, Johnson EE, Knutson MD, WesslingResnick M, Cherayil BJ: The iron efflux protein ferroportin regulates the intracellular growth of Salmonella enterica. Infect Immun 2006, 74:3065-3067.

5. Bullen JJ, Rogers HJ, Spalding PB, Ward CG: Natural resistance, iron and infection: a challenge for clinical medicine. J Med Microbio/ 2006, 55:251-258.

6. Schaible UE, Kaufmann SH: Iron and microbial infection. Nat Rev Microbiol 2004, 2:946-953.

7. Kehrer JP: The Haber-Weiss reaction and mechanisms of toxicity. Toxicology 2000, 149:43-50.

8. Theurl I, Fritsche G, Ludwiczek S, Garimorth K, Bellmann-Weiler R, Weiss G: The macrophage: a cellular factory at the interphase between iron and immunity for the control of infections. Biometals 2005, 18:359-367.

9. Howe D, Mallavia LP: Coxiella burnetii infection increases transferrin receptors on J774A. 1 cells. Infect Immun 1999, 67:3236-3241.

10. Barnewall RE, Ohashi N, Rikihisa Y: Ehrlichia chaffeensis and E. sennetsu, but not the human granulocytic ehrlichiosis agent, colocalize with transferrin receptor and up-regulate transferrin receptor mRNA by activating iron-responsive protein 1. Infect Immun 1999, 67:2258-2265

11. Clemens DL, Horwitz MA: The Mycobacterium tuberculosis phagosome interacts with early endosomes and is accessible to exogenously administered transferrin. J Exp Med 1996, 184:1349-1355.

12. Steele-Mortimer $\mathrm{O}$ : The Salmonella-containing vacuole-Moving with the times. Curr Opin Microbiol 2008, 11:38-45.

13. Clemens DL, Lee BY, Horwitz MA: Virulent and avirulent strains of Francisella tularensis prevent acidification and maturation of their phagosomes and escape into the cytoplasm in human macrophages. Infect Immun 2004, 72:3204-3217.

14. Deng K, Blick RJ, Liu W, Hansen EJ: Identification of Francisella tularensis genes affected by iron limitation. Infect Immun 2006, 74:4224-4236.

15. Sullivan JT, Jeffery EF, Shannon JD, Ramakrishnan G: Characterization of the siderophore of Francisella tularensis and role of $\mathrm{fsIA}$ in siderophore production. J Bacteriol 2006, 188:3785-3795.

16. Su J, Yang J, Zhao D, Kawula TH, Banas JA, Zhang JR: Genome-wide identification of Francisella tularensis virulence determinants. Infect Immun 2007, 75:3089-3101.

17. Weiss DS, Brotcke A, Henry T, Margolis JJ, Chan K, Monack DM: In vivo negative selection screen identifies genes required for Francisella virulence. Proc Natl Acad Sci USA 2007, 104:6037-6042.

18. Lenco J, Hubalek M, Larsson P, Fucikova A, Brychta M, Macela A, Stulik J: Proteomics analysis of the Francisella tularensis LVS response to iron restriction: induction of the $F$. tularensis pathogenicity island proteins IgIABC. FEMS Microbiol Lett 2007, 269:11-21.

19. Pekarek RS, Bostian KA, Bartelloni PJ, Calia FM, Beisel WR: The effects of Francisella tularensis infection on iron metabolism in man. Am J Med Sci 1969, 258:14-25

20. McKenna WR, Mickelsen PA, Sparling PF, Dyer DW: Iron uptake from lactoferrin and transferrin by Neisseria gonorrhoeae. Infect Immun 1988, 56:785-791.

21. Ratledge C, Dover LG: Iron metabolism in pathogenic bacteria. Annu Rev Microbiol 2000, 54:881-941.

22. Braun V: Iron uptake mechanisms and their regulation in pathogenic bacteria. Int J Med Microbiol 2001, 291:67-79.

23. Lindgren H, Honn M, Golovlev I, Kadzhaev K, Conlan W, Sjostedt A: The 58kilodalton major virulence factor of Francisella tularensis is required for efficient utilization of iron. Infect Immun 2009, 77:4429-4436. 
24. Rohmer L, Brittnacher M, Svensson K, Buckley D, Haugen E, Zhou Y, Chang J, Levy R, Hayden H, Forsman M, Olson M, Johansson A, Kaul R, Miller SI: Potential source of Francisella tularensis live vaccine strain attenuation determined by genome comparison. Infect Immun 2006, 74:6895-6906.

25. Hashim S, Mukherjee K, Raje M, Basu SK, Mukhopadhyay A: Live Salmonella modulate expression of Rab proteins to persist in a specialized compartment and escape transport to lysosomes. J Biol Chem 2000, 275:16281-16288.

26. Steele-Mortimer O, Meresse S, Gorvel JP, Toh BH, Finlay BB: Biogenesis of Salmonella typhimurium-containing vacuoles in epithelial cells involves interactions with the early endocytic pathway. Cell Microbiol 1999, 1:33-49.

27. Simpson JC, Jones AT: Early endocytic Rabs: functional prediction to functional characterization. Biochem Soc Symp 2005, 99-108.

28. Nairz M, Theurl I, Ludwiczek S, Theurl M, Mair SM, Fritsche G, Weiss G: The co-ordinated regulation of iron homeostasis in murine macrophages limits the availability of iron for intracellular Salmonella typhimurium. Cell Microbiol 2007, 9:2126-2140.

29. Kakhlon O, Cabantchik Zl: The labile iron pool: characterization, measurement, and participation in cellular processes(1). Free Radic Biol Med 2002, 33:1037-1046.

30. Rothman RJ, Serroni A, Farber JL: Cellular pool of transient ferric iron, chelatable by deferoxamine and distinct from ferritin, that is involved in oxidative cell injury. Mol Pharmacol 1992, 42:703-710.

31. Breuer W, Epsztejn S, Cabantchik ZI: Iron acquired from transferrin by K562 cells is delivered into a cytoplasmic pool of chelatable iron(II). $J$ Biol Chem 1995, 270:24209-24215.

32. Uchiya K, Barbieri MA, Funato K, Shah AH, Stahl PD, Groisman EA: A Salmonella virulence protein that inhibits cellular trafficking. Embo $J$ 1999, 18:3924-3933.

33. Ochman H, Soncini FC, Solomon F, Groisman EA: Identification of a pathogenicity island required for Salmonella survival in host cells. Proc Natl Acad Sci USA 1996, 93:7800-7804

34. Ohgami RS, Campagna DR, McDonald A, Fleming MD: The Steap proteins are metalloreductases. Blood 2006, 108:1388-1394.

35. Andrews NC, Schmidt PJ: Iron homeostasis. Annu Rev Physiol 2007, 69:69-85.

36. Hentze MW, Muckenthaler MU, Andrews NC: Balancing acts: molecular control of mammalian iron metabolism. Cell 2004, 117:285-297.

37. Donovan A, Brownlie A, Zhou Y, Shepard J, Pratt SJ, Moynihan J, Paw BH, Drejer A, Barut B, Zapata A, Law TC, Brugnara C, Lux SE, Pinkus GS, Pinkus JL, Kingsley PD, Palis J, Fleming MD, Andrews NC, Zon LI: Positional cloning of zebrafish ferroportin1 identifies a conserved vertebrate iron exporter. Nature 2000, 403:776-781.

38. Peyssonnaux C, Zinkernagel AS, Datta $V$, Lauth $X$, Johnson RS, Nizet V: TLR4-dependent hepcidin expression by myeloid cells in response to bacterial pathogens. Blood 2006, 107:3727-3732.

39. Ludwiczek S, Aigner E, Theurl I, Weiss G: Cytokine-mediated regulation of iron transport in human monocytic cells. Blood 2003, 101:4148-4154

40. Nguyen NB, Callaghan KD, Ghio AJ, Haile DJ, Yang F: Hepcidin expression and iron transport in alveolar macrophages. Am J Physiol Lung Cell Mol Physiol 2006, 291:L417-25.

41. Nicolas G, Viatte L, Lou DQ, Bennoun M, Beaumont C, Kahn A, Andrews NC, Vaulont S: Constitutive hepcidin expression prevents iron overload in a mouse model of hemochromatosis. Nat Genet 2003, 34:97-101.

42. Cole LE, Elkins KL, Michalek SM, Qureshi N, Eaton LJ, Rallabhandi P, Cuesta N, Vogel SN: Immunologic consequences of Francisella tularensis live vaccine strain infection: role of the innate immune response in infection and immunity. J Immunol 2006, 176:6888-6899.

43. Devireddy LR, Gazin C, Zhu X, Green MR: A cell-surface receptor for lipocalin 24p3 selectively mediates apoptosis and iron uptake. Cell 2005, 123:1293-1305.

44. Flo TH, Smith KD, Sato S, Rodriguez DJ, Holmes MA, Strong RK, Akira S, Aderem A: Lipocalin 2 mediates an innate immune response to bacterial infection by sequestrating iron. Nature 2004, 432:917-921.

45. Morse D, Choi AM: Heme oxygenase-1: from bench to bedside. Am J Respir Crit Care Med 2005, 172:660-670.

46. Orozco LD, Kapturczak MH, Barajas B, Wang X, Weinstein MM, Wong J, Deshane J, Bolisetty S, Shaposhnik Z, Shih DM, Agarwal A, Lusis AJ,
Araujo JA: Heme oxygenase-1 expression in macrophages plays a beneficial role in atherosclerosis. Circ Res 2007, 100:1703-1711.

47. Byrd TF, Horwitz MA: Interferon gamma-activated human monocytes downregulate transferrin receptors and inhibit the intracellular multiplication of Legionella pneumophila by limiting the availability of iron. J Clin Invest 1989, 83:1457-1465.

48. Byrd TF, Horwitz MA: Aberrantly low transferrin receptor expression on human monocytes is associated with nonpermissiveness for Legionella pneumophila growth. J Infect Dis 2000, 181:1394-1400.

49. Barnewall RE, Rikihisa Y, Lee EH: Ehrlichia chaffeensis inclusions are early endosomes which selectively accumulate transferrin receptor. Infect Immun 1997, 65:1455-1461.

50. Olakanmi O, Britigan BE, Schlesinger LS: Gallium disrupts iron metabolism of mycobacteria residing within human macrophages. Infect Immun 2000, 68:5619-5627.

51. Olakanmi O, Schlesinger LS, Ahmed A, Britigan BE: Intraphagosomal Mycobacterium tuberculosis acquires iron from both extracellular transferrin and intracellular iron pools. Impact of interferon-gamma and hemochromatosis. J Biol Chem 2002, 277:49727-49734.

52. Gobin J, Horwitz MA: Exochelins of Mycobacterium tuberculosis remove iron from human iron-binding proteins and donate iron to mycobactins in the M. tuberculosis cell wall. J Exp Med 1996, 183:1527-1532.

53. Miller JH: Cold Spring Harbor, NY, USA: Cold Spring Harbor Laboratory 1972.

54. Maier TM, Havig A, Casey M, Nano FE, Frank DW, Zahrt TC: Construction and characterization of a highly efficient Francisella shuttle plasmid. App Environ Microbiol 2004, 70:7511-7519.

55. Lee AH, Papari M, Daefler S: Identification of a NIPSNAP homologue as host cell target for Salmonella virulence protein SpiC. Cell Microbiol 2002, 4:739-750.

56. Epsztejn S, Kakhlon O, Glickstein H, Breuer W, Cabantchik I: Fluorescence analysis of the labile iron pool of mammalian cells. Anal Biochem 1997, 248:31-40

doi:10.1186/1471-2180-10-64

Cite this article as: Pan et al: Modulation of iron homeostasis in macrophages by bacterial intracellular pathogens. BMC Microbiology 2010 10:64

\section{Submit your next manuscript to BioMed Central and take full advantage of:}

- Convenient online submission

- Thorough peer review

- No space constraints or color figure charges

- Immediate publication on acceptance

- Inclusion in PubMed, CAS, Scopus and Google Scholar

- Research which is freely available for redistribution
Biomed Central 